\title{
Article \\ Comparative Study on Biodegradation of Pure Iron Prepared by Microwave Sintering and Laser Melting
}

\author{
Yingchao Zhao ${ }^{1}$, Jun Feng ${ }^{1, *}$, Hui Yu ${ }^{1}$, Wangyang $\operatorname{Lin}^{1}{ }^{1}$, Xin $\mathrm{Li}^{2}$, Yan Tian ${ }^{2}$ and Mingchun Zhao ${ }^{2} \mathbb{D}$ \\ 1 College of Mechanical Engineering, University of South China, Hengyang 421001, China; \\ 2020000102@usc.edu.cn (Y.Z.); vander_yu@usc.edu.cn (H.Y.); bruce3lin@usc.edu.cn (W.L.) \\ 2 School of Materials Science and Engineering, Central South University, Changsha 410083, China; \\ 1x1122@csu.edu.cn (X.L.); 163111055@csu.edu.cn (Y.T.); mczhao@csu.edu.cn (M.Z.) \\ * Correspondence: speedfjkang@163.com
}

Citation: Zhao, Y.; Feng, J.; Yu, H.; Lin, W.; Li, X.; Tian, Y.; Zhao, M. Comparative Study on Biodegradation of Pure Iron Prepared by Microwave Sintering and Laser Melting. Materials 2022, 15, 1604. https://doi.org/10.3390/ma15041604

Academic Editor:

Donatella Giuranno

Received: 19 January 2022

Accepted: 17 February 2022

Published: 21 February 2022

Publisher's Note: MDPI stays neutral with regard to jurisdictional claims in published maps and institutional affiliations.

Copyright: (c) 2022 by the authors. Licensee MDPI, Basel, Switzerland. This article is an open access article distributed under the terms and conditions of the Creative Commons Attribution (CC BY) license (https:// creativecommons.org/licenses/by/ $4.0 /)$.

\begin{abstract}
For biodegradable pure iron implants, a higher biodegradation rate is preferred. In this work, we compared the biodegradation of pure iron prepared by microwave sintering and laser melting (designated as MSed Fe and LMed Fe, respectively). The MSed Fe presented a distinct porous structure, while the LMed Fe presented a relatively compact structure without any obvious pores. The biodegradation rate of the MSed Fe was higher than that of the LMed Fe, and their biodegradation rates were higher than that of the as-cast Fe. The biodegradation rates of the MSed Fe and the LMed Fe were approximately 44 and 13 times higher than that of the as cast $\mathrm{Fe}$, respectively. The biodegradation was closely related to the microstructure's compactness and grain size. Moreover, the MSed Fe and the LMed Fe had satisfactory biocompatibility.
\end{abstract}

Keywords: pure iron; biodegradation; biocompatibility; microwave sintering; laser melting

\section{Introduction}

Pure iron is an ideal biodegradable metallic stent material [1-4], which does not create gas or cause the alkalinization of body fluids during the biodegradation process. It is degraded and absorbable even after the remodeling of the blood vessel. A pure iron implant did not lose its supporting function after an operation, and effectively prevented the elastic retraction of the blood vessel. There was no obvious inflammation in the local tissues and no obvious proliferation of the vascular intima, showing satisfactory histocompatibility [5,6]. However, a stent strut of pure iron can remain in blood vessels for over 1 year [7], which means that the biodegradation rate of a pure iron implant is too slow. An implant remaining in a body for an extended period of time will harm healthy tissues, and may create other symptoms. Though the future use of pure iron as a biomedical implant material is promising, it requires an appropriate biodegradation rate in body fluid environments to meet the requirements for clinical application.

Many studies have indicated that the biodegradation of iron-based alloys depends on the grain size, i.e., a finer grain size leads to a higher biodegradation rate for Fe-based alloys $[8,9]$. The grain refinement of pure iron provides a promising research direction for improving its biodegradation rate. Microwave sintering and laser melting are new methods for rapid prototyping. Microwave sintering shortens the sintering time and improves element diffusion due to its superior uniform heating and higher microwave heating efficiency compared to conventional sintering [10]. Laser melting cools remarkably fast upon solidification due to its rapid melting rate. This is because the material powders begin rapid in situ cooling in the melt pool [11,12]. Therefore, both microwave sintering and laser melting can easily produce fine grain sizes, and thus are expected to produce pure iron with an increased degradation rate. In addition, microwave sintering and laser melting are net-shape manufacturing techniques, which may produce patient-specific implants with minimal post-processing and shorter lead time compared to conventional manufacturing 
methods such as casting. So far, both microwave sintering and laser melting have been successfully used to produce iron in biomedical applications $[13,14]$. However, these studies mostly focused on processing or comparing novel manufacturing methods or alloys to conventionally manufactured pure iron. The differences in the biodegradation of pure iron prepared by microwave sintering (MSed Fe) and pure iron prepared by laser melting (LMed Fe) are not yet understood. It is difficult to directly compare the biodegradation results in different studies because they were each significantly influenced by experimental parameters [15]. Therefore, it is important to directly compare the influence of net-shape manufacturing techniques (microwave sintering and laser melting) on the biodegradation of pure iron. To the best of our knowledge, no work comparing their biodegradation has been previously conducted.

In this study, we used pure iron powder to prepare biodegradable pure iron by microwave sintering and laser melting, separately, and compared the microstructure, hardness, biodegradation, and cytocompatibility of both the MSed Fe and the LMed Fe, paying special attention to their biodegradation.

\section{Experiments}

The pure iron powders used in this study were $99.9 \%$ pure, containing (by mass) $0.02 \% \mathrm{Mn}, 0.01 \% \mathrm{Cr}, 0.01 \% \mathrm{Ni}, 0.003 \% \mathrm{C}, 0.03 \% \mathrm{O}, 0.004 \% \mathrm{P}$, and $0.005 \% \mathrm{~S}$ (purchased from Changsha Tid Metal Materials Co., Ltd., Changsha, China). Figure 1a presents the morphology of the pure iron powders observed by a scanning electron microscope (SEM, ZEISS EVO-18, Jena, Germany), which contained irregular massive clumps, having an average particle diameter of $\sim 30 \mu \mathrm{m}$. Figure $1 \mathrm{~b}$ presents the X-ray diffraction pattern (XRD, with $\mathrm{Cu}-\mathrm{K} \alpha$ radiation at $30 \mathrm{~mA}$ and $40 \mathrm{kV}$ using $8^{\circ} \mathrm{min}^{-1}$ ) of the pure iron powders, in which the three strongest diffraction peaks correspond to $\alpha-\mathrm{Fe}$, and the other small peaks correspond to surface iron oxide, which formed due to minor atmospheric exposure. This indicated that the purity of the pure iron powders were high and without other impurities.
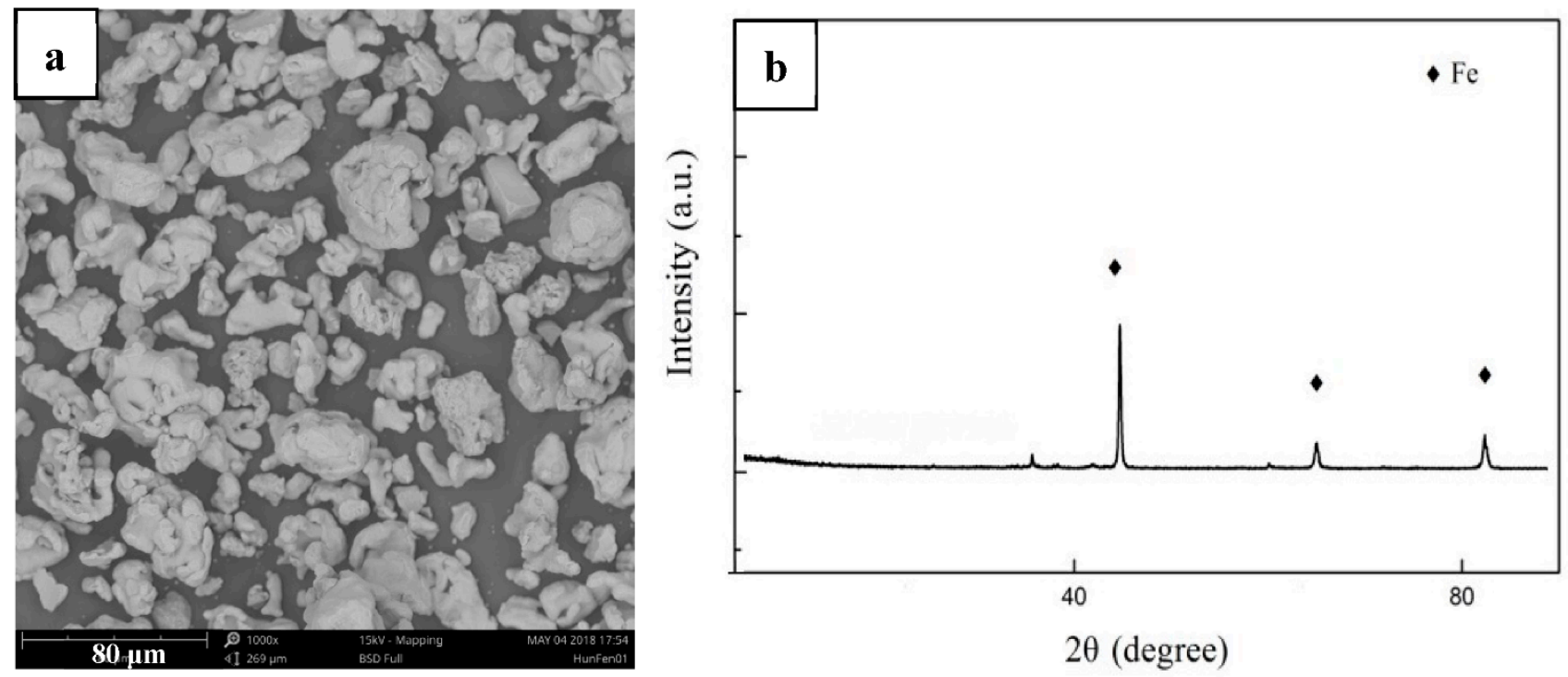

Figure 1. SEM morphology (a) and XRD pattern (b) of the pure iron powders.

For microwave sintering, cylindrical specimens $(\Phi 10 \mathrm{~mm} \times 5 \mathrm{~mm})$ were obtained by uniaxially compacting pure iron powders for $2 \mathrm{~min}$ at $600 \mathrm{MPa}$, which were demolded by a mold wall lubricant of zinc stearate at $12 \mathrm{~mm} / \mathrm{min}$. The obtained specimens were placed in a ceramic crucible microwave acceptor that was set in the glass tube of a microwave sintering furnace (HY-ZG1512, Changsha, China) with $2.45 \mathrm{GHz} 4 \mathrm{~kW}$, and was heated by the microwave at $20-1100{ }^{\circ} \mathrm{C} / \mathrm{min}$, sintering for $10 \mathrm{~min}$, and then furnace-cooled to room temperature. For laser melting, biodegradable pure iron was fabricated by a self-regulating 
selective $75 \mathrm{~W}$ laser with a $150 \mu \mathrm{m}$ laser spot size, a scanning speed of $15 \mathrm{~mm} / \mathrm{s}$, and a $50 \mu \mathrm{m}$ hatch spacing and layer thickness. An "S" scan covered the cross section, which interlaced the lower and upper scanning lines. The high-purity Ar atmosphere was used to protect both the microwave sintering and the laser sintering processes.

Microstructures were observed by an optical microscope (OM, ZEISS Axio Vert Al, Jena, Germany), and the densities were measured using the Archimedes method. The Vickers hardness was measured by a microhardness tester (HV-1000, Shanghai, China) under a load of $2.942 \mathrm{~N}$ for $15 \mathrm{~s}$. An average hardness was obtained for each specimen by selecting 10 points randomly for a hardness measurement. The pore sizes were measured using direct observation of the cross-section [16]. The density was measured using Archimedes' principle [17].

The biodegradation was studied using a potentiodynamic polarization test and an immersion test, which were performed in Hank's solution (containing $8.00 \mathrm{~g} / \mathrm{L} \mathrm{NaCl}, 0.40$ $\mathrm{g} / \mathrm{L} \mathrm{KCl}, 0.10 \mathrm{~g} / \mathrm{L} \mathrm{MgCl}_{2} \cdot 6 \mathrm{H}_{2} \mathrm{O}, 0.35 \mathrm{~g} / \mathrm{L} \mathrm{NaHCO}_{3}, 0.10 \mathrm{~g} / \mathrm{L} \mathrm{MgSO} 4 \cdot 7 \mathrm{H}_{2} \mathrm{O}, 0.14 \mathrm{~g} / \mathrm{L} \mathrm{CaCl}_{2}$, $0.12 \mathrm{~g} / \mathrm{L} \mathrm{Na}_{2} \mathrm{HPO}_{4} \cdot 12 \mathrm{H}_{2} \mathrm{O}, 0.06 \mathrm{~g} / \mathrm{L} \mathrm{KH}_{2} \mathrm{PO}_{4}$, and $1.00 \mathrm{~g} / \mathrm{L}$ glucose) with a $\mathrm{pH}$ of 7.6 at $37 \pm 0.5^{\circ} \mathrm{C}$. More details of the potentiodynamic polarization test and the immersion test have been documented elsewhere $[13,14]$. Corroded surfaces and topographic maps were observed by a SEM (ZEISS EVO-18, Jena, Germany) and a 3D measuring laser microscope (Barcelona, Spain) after the immersion test, separately. The degradation rate, $P_{i}(\mathrm{~mm} /$ year), was calculated from the potentiodynamic polarization test using Equation (1) [13], and the degradation rate, $P_{w}(\mathrm{~mm} /$ year $)$, was calculated from immersion test using Equation (2) [14].

$$
\begin{gathered}
P_{i}=1.337 \times 10^{-2} i_{\text {corr }} \\
P_{w}=3.67\left(W_{\mathrm{i}}-W_{\mathrm{f}}\right) /(A T D)
\end{gathered}
$$

where $i_{\text {corr }}$ is the current corrosion density $\left(\mu \mathrm{A} \mathrm{cm}{ }^{-2}\right), W_{\mathrm{i}}$ is the initial mass before immersion $(\mathrm{g}), W_{\mathrm{f}}$ is the final mass after immersion $(\mathrm{g}), A$ is the area exposed to the solution $\left(\mathrm{cm}^{2}\right)$, $D$ is density $\left(\mathrm{g} / \mathrm{cm}^{3}\right)$, and $T$ is time $(\mathrm{d})$.

MG63 cells and ISO 1093-5 indirect contact method were used to detect the cytocompatibility with a fluorescence microscope. More details were documented elsewhere [3]. The MG63 cell viability was calculated using Equation (3).

$$
\text { Cell Viability }=\left(\frac{O D_{\text {sample }}}{O D_{\text {negative }}}\right) \times 100 \%
$$

where $O D_{\text {sample }}$ is the sample optical densities and $O D_{\text {negative }}$ is the negative control.

\section{Results and Discussion}

\subsection{Microstructure and Hardness}

Figure 2 shows optical micrographs of MSed Fe and LMed Fe. MSed Fe presented an average ferrite size of $\sim 30 \mu \mathrm{m}$, some large pores $(\sim 70 \mu \mathrm{m})$, and small pores $(\sim 10 \mu \mathrm{m})$ distributed randomly on its surface. The mechanism of randomly distributed pores on the surface of MSed Fe was ascribed to one or more of the following: (i) power gap, (ii) Kirkendall pores [18], and (iii) impurity evaporation. LMed Fe presented a relatively compact microstructure without any obvious pores, consisting of irregular polygonal ferrite grains, with an average ferrite grain size of $\sim 30 \mu \mathrm{m}$. On average, MSed Fe and LMed Fe had smaller ferrite grain sizes than the conventional as cast Fe (with an average ferrite grain size of $\sim 500 \mu \mathrm{m}$ [19] or $\sim 350 \mu \mathrm{m}$ [4]). This indicated that a fine ferrite grain size can be produced by microwave sintering or laser melting. 

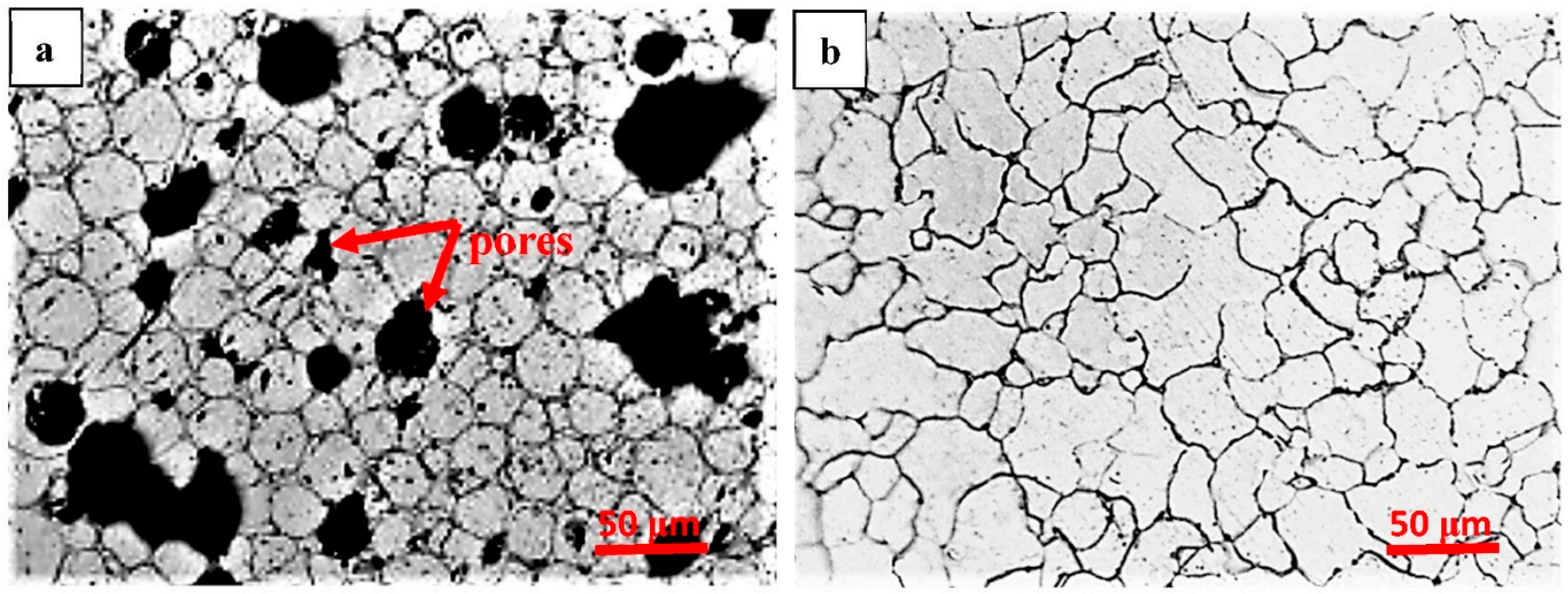

Figure 2. Optical micrographs of both the MSed Fe (a) and the LMed Fe (b).

Table 1 lists the density, relative density, and hardness of MSed Fe, LMed Fe, and ascast Fe. The density of MSed Fe was $\sim 6.85 \mathrm{~g} / \mathrm{cm}^{3}$, while the density of LMed Fe was higher, at $\sim 7.61 \mathrm{~g} / \mathrm{cm}^{3}$. The relative density of MSed Fe was $\sim 87.04 \%$, while the relative density of LMed Fe was higher, at $\sim 96.2 \%$. The density and the relative density of the conventional as cast Fe were $7.87 \mathrm{~g} / \mathrm{cm}^{3}$ and $99.9 \%$, respectively [4]. Therefore, the measured density and relative density indicated that MSed Fe had a porous structure, while LMed Fe had a relatively compact structure, which reflected the microstructure characteristics shown in Figure 2. The hardness of MSed Fe was $\sim 101 \mathrm{HV}$ and that of the LMed Fe was $\sim 113 \mathrm{HV}$, higher than that of the conventional as cast Fe, which was $~ 63 \mathrm{HV}$ [19]. This indicated that microwave sintering and laser melting markedly increased hardness. The hardness contribution of the grain refinement was inverse to the grain size, according to the HallPetch relation [20]. Thus, hardening was attributed to the grain refinement produced by microwave sintering and laser melting. Furthermore, the hardness of the LMed Fe was higher than that of the MSed Fe, which was attributed to the relatively compact structure in the LMed Fe, rather than the porous structure in the MSed Fe.

Table 1. Density and hardness of MSed Fe and LMed Fe.

\begin{tabular}{cccc}
\hline & MSed Fe & LMed Fe & As-Cast Fe \\
\hline Density $\left(\mathrm{g} / \mathrm{cm}^{3}\right)$ & $6.85 \pm 0.03$ & $7.61 \pm 0.04$ & $7.87[4]$ \\
Relative density $(\%)$ & $87.04 \pm 0.04$ & $96.2 \pm 0.02$ & $99.9[4]$ \\
Hardness (HV) & $101 \pm 2$ & $113 \pm 1$ & $63[19]$ \\
\hline
\end{tabular}

\subsection{Biodegradation}

Figure 3 presents the potentiodynamic polarization curves of the freshly prepared MSed Fe and LMed Fe. The corrosion potential ( $\left.E_{\text {corr }}\right)$ of MSed Fe was $-0.41 \mathrm{~V} / \mathrm{SCE}$, while the corrosion potential of LMed Fe was $-0.43 \mathrm{~V} / \mathrm{SCE}$. The corrosion current density ( $i_{\text {corr }}$ ) of MSed Fe was $29 \mu \mathrm{A} \mathrm{cm}{ }^{-2}$, and that of LMed Fe was $14.5 \mu \mathrm{A} \mathrm{cm}{ }^{-2}$, which was measured from the linear cathodic branch of the polarization potential curves using Tafel extrapolation [21,22]. Their biodegradation rates were calculated from $i_{\text {corr }}$ using Equation (1), which are listed in Table 2. 


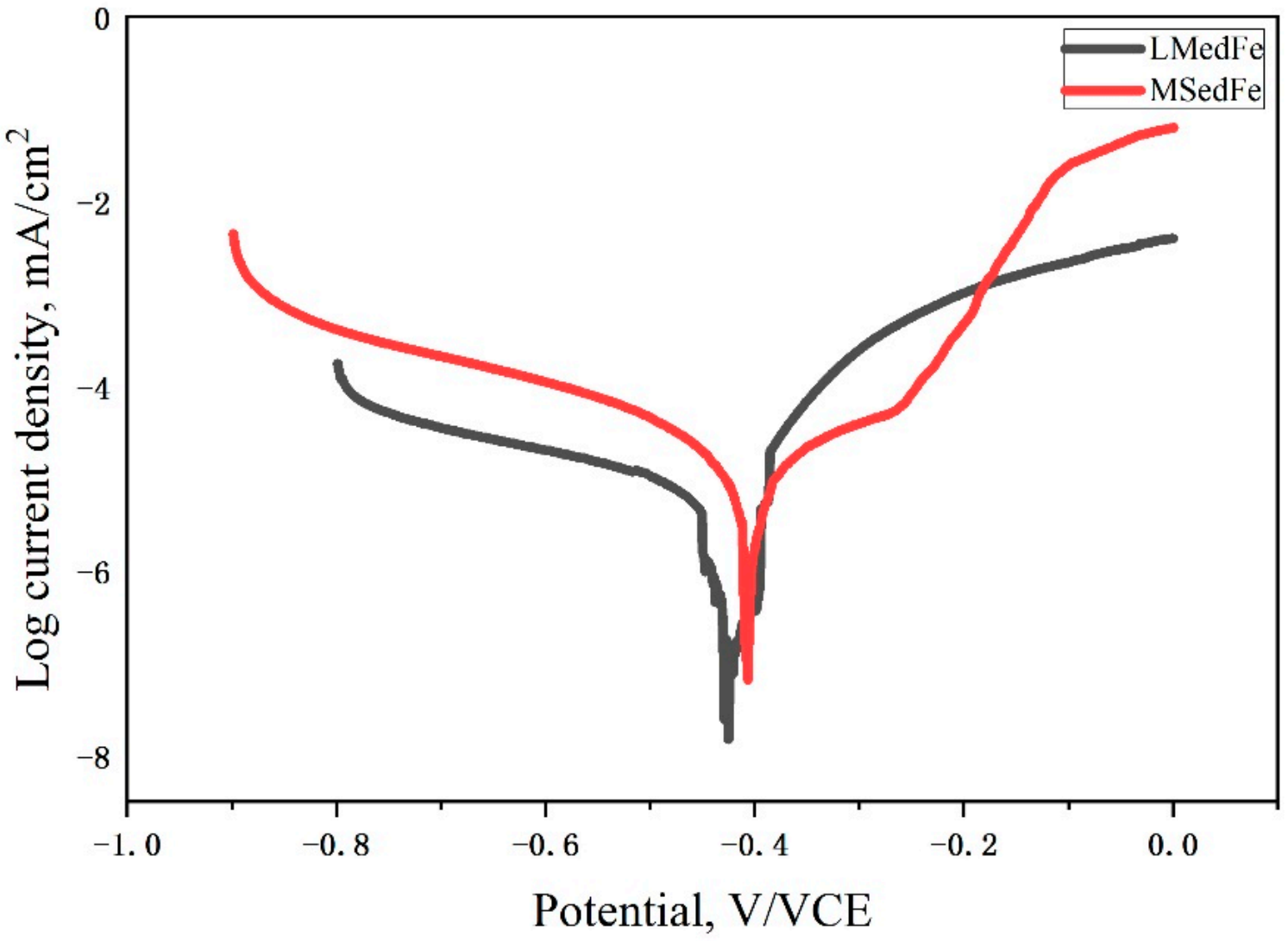

Figure 3. Potentiodynamic polarization curves of MSed Fe and LMed Fe.

Table 2. Density and hardness of MSed Fe and LMed Fe.

\begin{tabular}{cccc}
\hline & MSed Fe & LMed Fe & As-Cast Fe \\
\hline$i_{\text {corr }}, \mu \mathrm{A} / \mathrm{cm}^{2}$ & $29 \pm 0.04$ & $14.5 \pm 0.03$ & $4.05[4]$ \\
$P_{i}, \mathrm{~mm} /$ year & $0.39 \pm 0.002$ & $0.20 \pm 0.002$ & - \\
$\left(W_{\mathrm{b}}-W_{\mathrm{a}}\right) / A T, \mathrm{mg} /\left(\mathrm{cm}^{2}\right.$ day $)$ & $0.65 \pm 0.003$ & $0.19 \pm 0.001$ & - \\
$P_{w}, \mathrm{~mm} /$ year & $0.35 \pm 0.002$ & $0.10 \pm 0.001$ & $0.008[23]$ \\
\hline
\end{tabular}

The biodegradation rates of MSed Fe and LMed Fe over 30 days' immersion is also listed in Table 2, which were calculated from the weight loss using Equation (2). The biodegradation rate from weight loss and that determined from polarization curves gave the same trends, as shown in Table 2, i.e., MSed Fe had a higher biodegradation rate determined from both weight loss or polarization curves compared to LMed Fe. The biodegradation rate was determined from the polarization curves involved in the biodegradation onset, whereas the biodegradation rate determined from the weight loss used the average biodegradation, which included biodegradation for some time after its onset. The biodegradation rate from the weight loss was more realistic, at $0.35 \mathrm{~mm} /$ year for MSed Fe, $0.10 \mathrm{~mm} /$ year for LMed Fe, and $0.008 \mathrm{~mm} /$ year for as-cast Fe [23]. Therefore, MSed Fe had the highest biodegradation rate, the LMed Fe had the second highest, leaving as-cast Fe with the lowest biodegradation rate.

Figure 4 presents the average released MSed Fe and LMed Fe concentrations, which were immersed in Hank's solution for 30 days. The average daily released iron ion concentration was $5.15 \mu \mathrm{g} /(\mathrm{mL}$ day) for MSed Fe and $4.33 \mu \mathrm{g} /(\mathrm{mL}$ day) for LMed Fe. As documented [23], the average daily released iron ion concentration was $\sim 3 \mu \mathrm{g} /(\mathrm{mL}$ day) for as-cast Fe. A higher released iron ion concentration indicates a faster biodegradation rate [24], showing that MSed Fe had a faster biodegradation rate than LMed Fe. Furthermore, these two had faster biodegradation rates than the as-cast Fe. This is consistent 
with the biodegradation rate determined from the weight loss and polarization curves mentioned above.

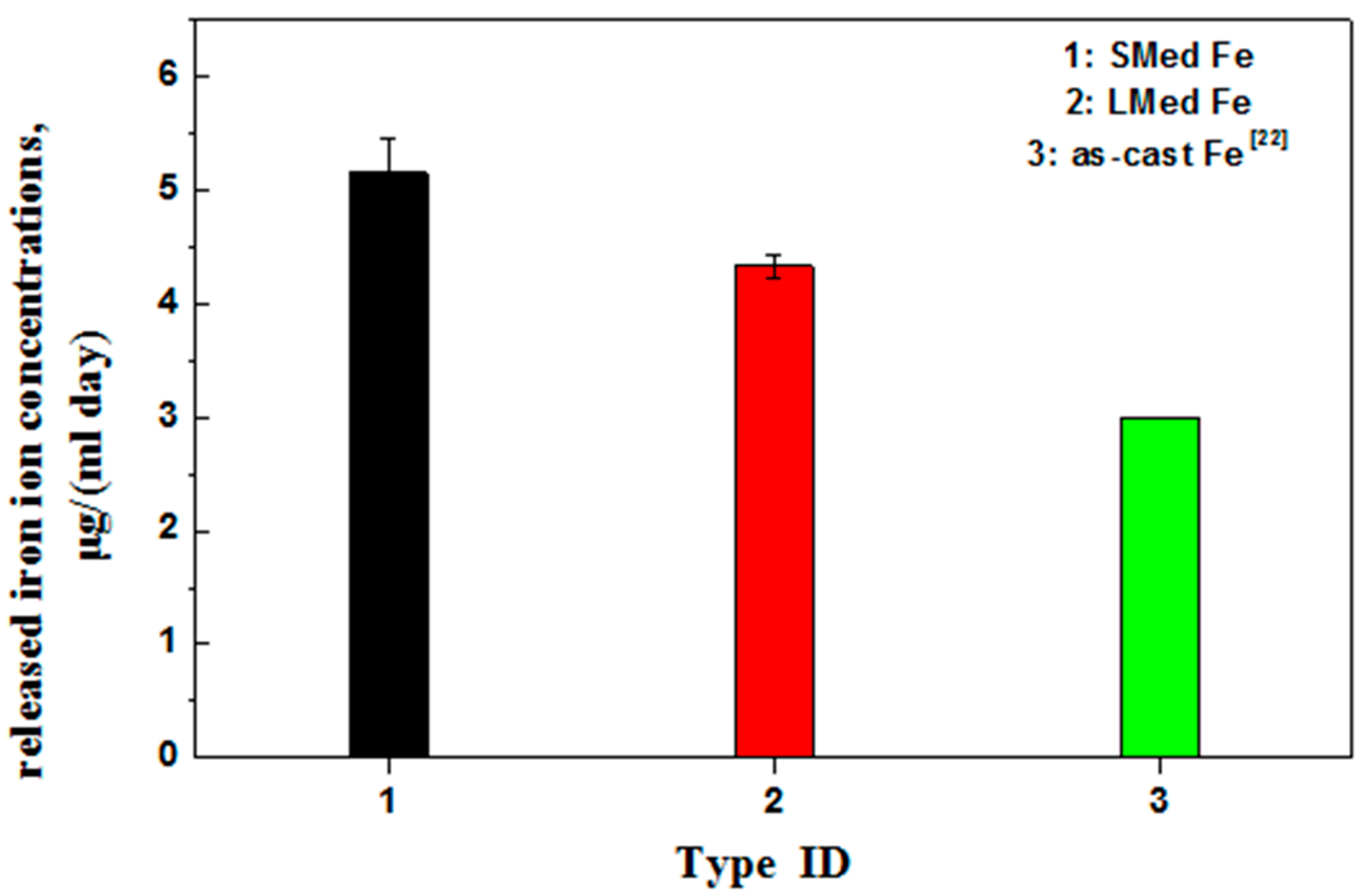

Figure 4. Average daily released iron ion concentrations of MSed Fe, LMed Fe, and as-cast Fe.

Figure 5 presents the surface appearances and the topographic maps after removing corrosion products for MSed Fe and LMed Fe after 30 days of immersion. Their surface appearances and topographic maps were very different, showing that LMed Fe corroded less. Compared to MSed Fe, LMed Fe showed relatively uniform biodegradation on a macro scale, and the entire corroded surface was homogenously covered by a thin layer of corrosion films. After washing using distilled water, their corresponding topographic maps depicted this difference in biodegradation, in which different colors corresponded to different corrosion depths. The corrosion depth of LMed Fe was shallow, with its deepest corrosion pit at $\sim 30 \mu \mathrm{m}$. In contrast, the corrosion depth of SMed Fe was relatively deeper, with its deepest corrosion pit at $\sim 200 \mu \mathrm{m}$.

When metal is implanted into the human body, metal ions are released due to the biodegradation reaction between the metal and the body's fluids. The biodegradation of the pure iron begins at the grain's boundaries due to the potential difference between the grain matrix and the grain boundary, and hence, a finer grain size results in a higher biodegradation rate. This is because the finer grains present more grain boundaries, and thus promote biodegradation. The cathodic reaction is: $2 \mathrm{H}_{2} \mathrm{O}+\mathrm{O}_{2}+4 \mathrm{e} \rightarrow 4 \mathrm{OH}^{-1}$, and the anodic reaction is: $\mathrm{Fe}-2 \mathrm{e} \rightarrow \mathrm{Fe}^{2+}$. Thus, the following reaction occurs: $\mathrm{Fe}^{2+}+2 \mathrm{OH}^{-1}$ $\rightarrow 2 \mathrm{Fe}(\mathrm{OH})_{2}$. The $\mathrm{Fe}(\mathrm{OH})_{2}$ is then oxidized into $\mathrm{Fe}(\mathrm{OH})_{3}$ due to its instability, followed by the reaction: $4 \mathrm{Fe}(\mathrm{OH})_{2}+\mathrm{O}_{2}+2 \mathrm{H}_{2} \mathrm{O} \rightarrow 4 \mathrm{Fe}(\mathrm{OH})_{3}$. This might be substantiated by the XRD pattern of the biodegradation product of LMed Fe, depicted in Figure 6a, which contained $\mathrm{Fe}(\mathrm{OH})_{3}$. When the biodegradation advanced, the $\mathrm{Ca} / \mathrm{P}$ compounds precipitated on the surface of the hydroxide layer, as demonstrated by the EDS results of LMed Fe. As depicted in Figure 6b, the surface biodegradation products contained O, Fe, Ca and P. In the present work, MSed Fe showed higher biodegradation rates than LMed 
Fe; these two had higher biodegradation rates than the as-cast Fe. The biodegradation rate was closely related to the compactness of the materials with the porous structure, as substantiated by previous studies $[13,25,26]$. The porous structure increased the actual area of the contact surface between the materials and the solution. The probable crevice corrosion happened in the porous structure, causing the biodegradation rate to increase. The biodegradation mechanism that was closely related to the compactness of the materials is illustrated in Figure $6 c$,d where Figure $6 c$ corresponds to the compact structure and Figure $6 \mathrm{~d}$ corresponds to the porous structure. As described in Figure 2 and Table 1, MSed Fe had a distinct porous structure, while LMed Fe had a relatively compact structure without any obvious pores. Consequentially, the resulting order of the biodegradation rate was as follows: MSed Fe > LMed Fe > as-cast Fe. Moreover, microwave sintering and laser melting caused a fine ferrite grain size. Compared to the as-cast Fe, the grain refinement of the MSed Fe and LMed Fe further promoted this trend.
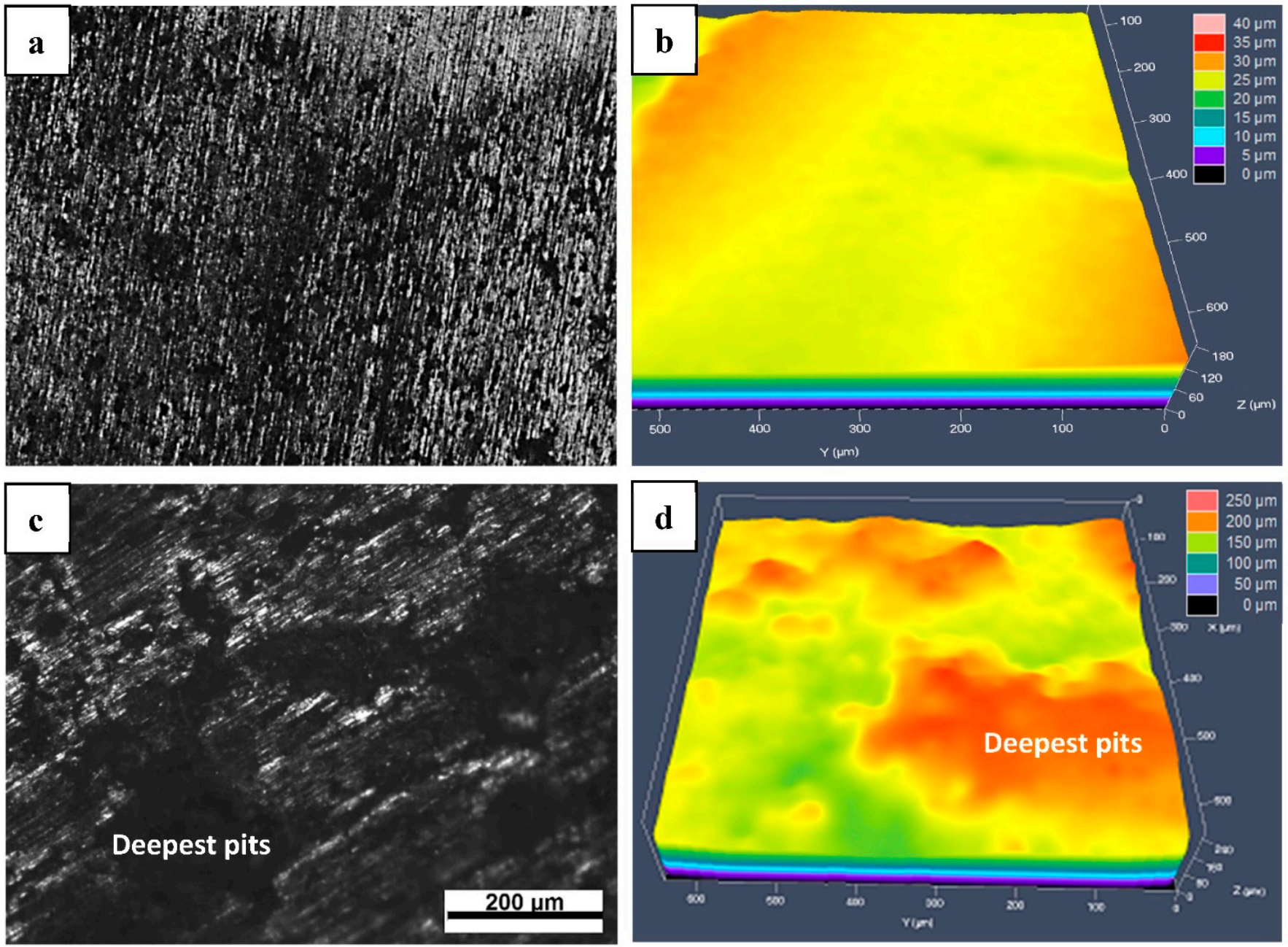

Figure 5. Surface appearances and topographic maps for LMed Fe (a,b) and MSed Fe (c,d). 

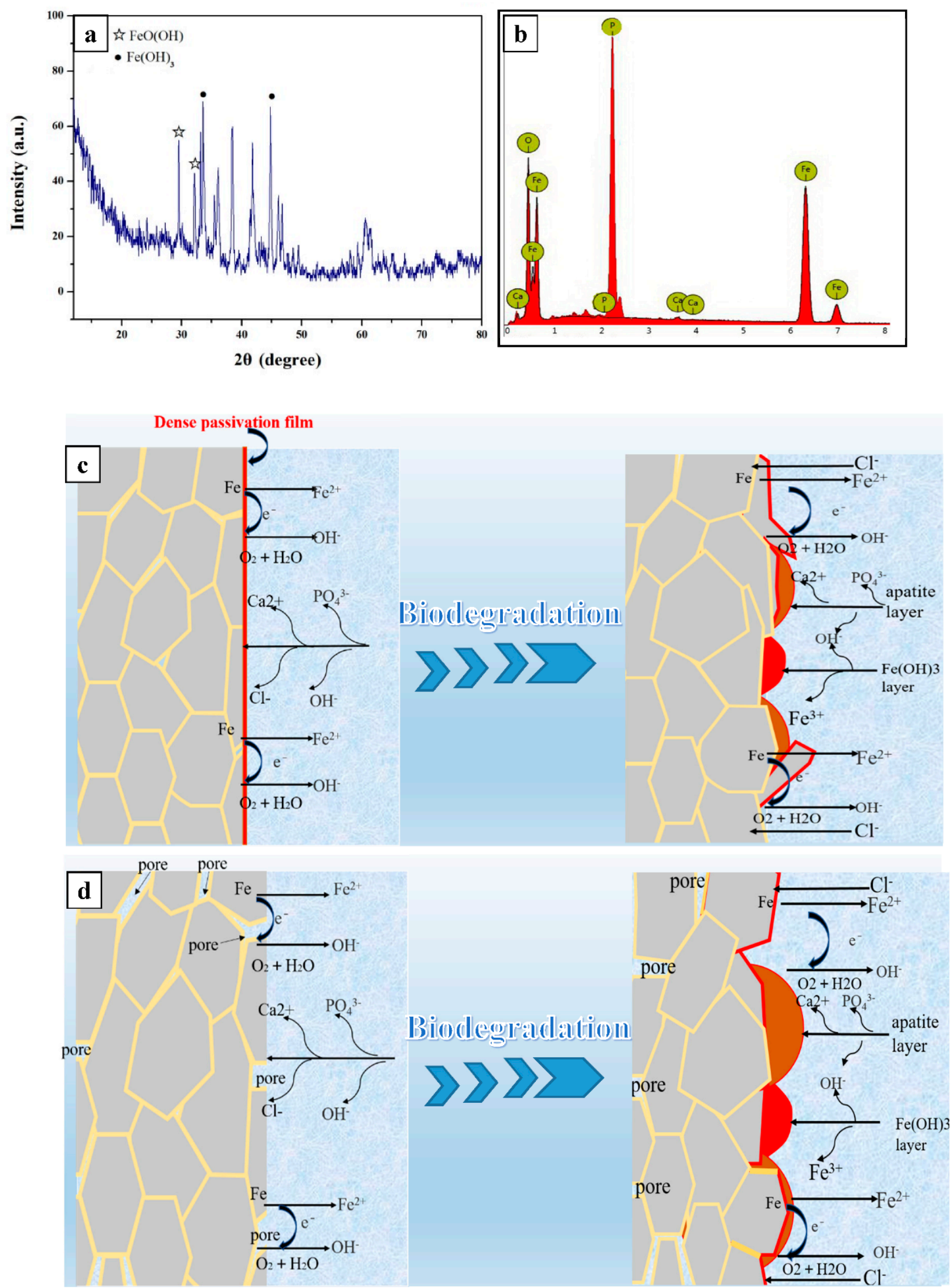

Figure 6. Illustration of biodegradation mechanism: (a) XRD; (b) EDS results of corrosion products; biodegradation corresponding to (c) the compact structure and (d) the porous structure. 


\subsection{Biocompatibility}

Figure 7 presents the MG63 cell fluorescence morphologies after culturing for 3 days, in which the living cells are green, and the dead cells are red. Compared to the control group (Figure 7a), the MG63 cell fluorescence morphology corresponding to the MSed Fe and LMed Fe showed little difference in cell densities (Figure $7 b, c)$. There were no dead cells and numerous living cells were observed in their fluorescence morphologies (Figure 7a-c), indicating normal cell proliferation. MG63 cell viabilities were higher than $90 \%$ in the control group (Figure 7d); therefore, the MSed Fe and the LMed Fe showed no cytotoxicity. Cell viability is a crucial indicator of cytocompatibility; thus, MSed Fe and LMed Fe had satisfactory cytocompatibility.
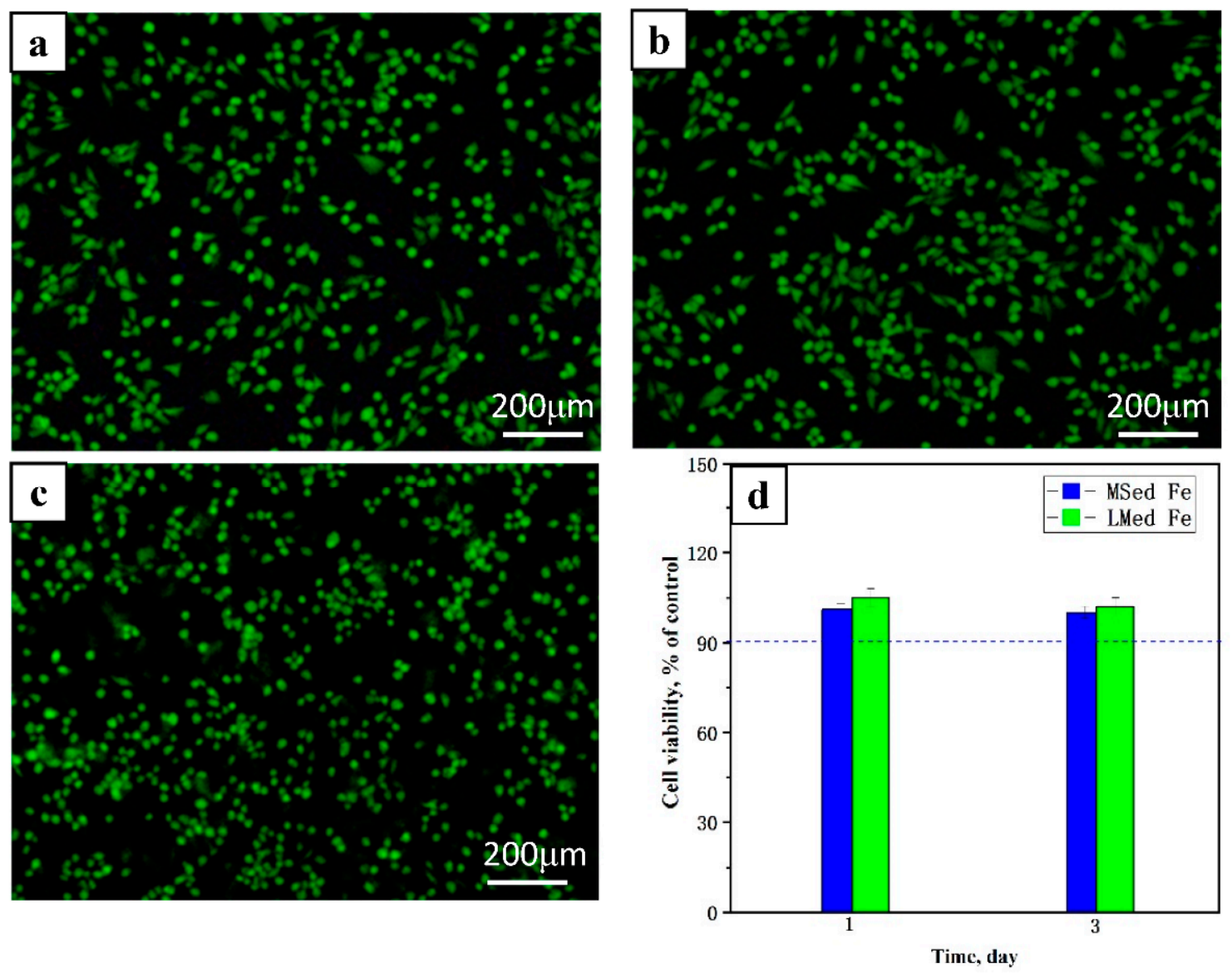

Figure 7. MG63 cell fluorescence morphologies after 3 day culture: (a) extracts, (b) MSed Fe, and (c) LMed Fe. Cell viability of MG63 cells in extracts of MSed Fe and LMed Fe after culturing 1 day and 3 days $(\mathbf{d})$.

Metal implant materials release metal ions due to biodegradation, which may be toxic to cells. In the present study, iron ions were released during biodegradation. Iron is an essential element in the human body [27,28], and a normal range of iron ion content is essential for various physiological and metabolic activities. An iron ion concentration of less than $10 \mu \mathrm{g} / \mathrm{mL}$ played a favorable role in endothelial cell metabolic activity, while an iron ion concentration of less than $50 \mu \mathrm{g} / \mathrm{mL}$ hardly inhibited the endothelial cell metabolic activities [29]. As shown in Figure 4, the average daily released iron ion concentration of MSed Fe was the highest, at $\sim 5.15 \mu \mathrm{g} /(\mathrm{mL}$ day), and that of LMed Fe was $\sim 4.33 \mu \mathrm{g} /(\mathrm{mL}$ day), which are far lower than the iron half-maximal inhibitory concentration $\left(\mathrm{IC}_{50}\right)$ [30], and are completely within the safe range of iron ion concentration in the human body. Therefore, the concentration of iron ions did not exceed the cell's physiological requirements, which was also supported by ion concentrations, cell fluorescence, and cell viability figures, 
as mentioned above. Furthermore, the biocompatibility of both MSed Fe and LMed Fe was acceptable.

\section{Conclusions}

This comparative study on the biodegradation of pure iron by microwave sintering and laser melting has shown that:

1. MSed Fe presented a distinct porous structure, while LMed Fe presented a relatively compact structure without any obvious pores.

2. MSed Fe had lower a density and hardness than LMed Fe, and both had lower density, but higher hardness than the as-cast Fe.

3. The order of the biodegradation rate was as follows: MSed Fe $>$ LMed Fe $>$ as-cast Fe. That is, the biodegradation rates of MSed Fe and LMed Fe were approximately 44 and 13 times higher than that of as-cast Fe, respectively.

4. Microwave sintering and laser melting were effective methods of increasing the biodegradation rate. The biodegradation behavior was closely related to the microstructure compactness and grain size.

5. MSed Fe and LMed Fe had satisfactory biocompatibility.

Author Contributions: Conceptualization, Y.Z. and M.Z.; methodology, J.F. and Y.Z.; software, H.Y.; validation, W.L. and X.L.; formal analysis, J.F.; investigation, H.Y.; resources, W.L.; data curation, X.L.; writing—original draft preparation, Y.Z.; writing_review and editing, M.Z.; visualization, Y.T.; supervision, M.Z.; project administration, Y.T. and M.Z.; funding acquisition, Y.Z. and J.F. All authors have read and agreed to the published version of the manuscript.

Funding: This research was funded by the PhD Scientific Research Start-up Fund of University of South China (grant No. 200XQD082 and grant No. 200XQD073).

Institutional Review Board Statement: Not applicable.

Informed Consent Statement: Not applicable.

Data Availability Statement: All data included in this study are available upon request by contact with the first author.

Conflicts of Interest: The authors declare no conflict of interest.

\section{References}

1. Gorejová, R.; Haverová, L.; Oriňaková, R.; Oriňak, A.; Oriňak, M. Recent advancements in Fe-based biodegradable materials for bone repair. J. Mater. Sci. 2019, 54, 1913-1947. [CrossRef]

2. Lee, M.K.; Lee, H.; Park, C.; Kang, I.G.; Kim, J.; Kim, H.E.; Jung, H.D.; Jang, T.S. Accelerated biodegradation of iron-based implants via tantalum-implanted surface nanostructures. Bioact. Mater. 2022, 9, 239-250. [CrossRef]

3. Guo, Y.X.; Zhao, M.C.; Xie, B.; Zhao, Y.C.; Yin, D.; Gao, C.; Shuai, C.; Atrens, A. In vitro corrosion resistance and antibacterial performance of novel fe-xcu biomedical alloys prepared by selective laser melting. Adv. Eng. Mater. 2020, 23, 2001000. [CrossRef]

4. Carluccio, D.; Bermingham, M.; Kent, D.; Demir, A.G.; Previtali, B.; Dargusch, M.S. Comparative study of pure iron manufactured by selective laser melting, laser metal deposition, and casting processes. Adv. Eng. Mater. 2018, 21, 1900049. [CrossRef]

5. Gasior, G.; Szczepanski, J.; Radtke, A. Biodegradable iron-based materials-what was done and what more can be done. Materials 2021, 14, 3381. [CrossRef] [PubMed]

6. Peuster, M.; Hesse, C.; Schloo, T.; Fink, C.; Beerbaum, P.; von Schna-Kenburg, C. Long-term biocompatibility of a corrodible peripheral iron stent in the porcine descending aorta. Biomaterials 2006, 27, 4955-4962. [CrossRef]

7. Kraus, T.; Moszner, F.; Fischerauer, S.; Fiedler, M.; Martinelli, E.; Eichler, J.; Witte, F.; Willbold, E.; Schinhammer, M.; Meischel, M.; et al. Biodegradable Fe-based alloys for use in osteosynthesis: Out-come of an in vivo study after 52 weeks. Acta Biomater. 2014, 10, 3346-3353. [CrossRef]

8. Moravej, M.; Prima, F.; Fiset, M.; Mantovani, D. Electroformed iron as new biomaterial for degradable stents: Development process and structure-properties relationship. Biomaterials 2010, 6, 1726-1735. [CrossRef]

9. Li, Y.; Jahr, H.; Lietaert, K.; Pavanram, P.; Yilmaz, A.; Fockaert, L.I.; Leeflang, M.A.; Pouran, B.; Gonzalez-Garcia, Y.; Weinans, H.; et al. Additively manufactured biodegradable porous iron. Acta Biomater. 2018, 77, 380-393. [CrossRef]

10. Oghbaei, M.; Mirzaee, O. Microwave versus conventional sintering: A review of fundamentals, advantages and applications. $J$. Alloy. Compd. 2010, 494, 175-189. [CrossRef] 
11. Xie, B.; Zhao, M.C.; Xu, R.; Zhao, Y.C.; Yin, D.F.; Gao, C.; Atrens, A. Biodegradation, Antibacterial Performance, and Cytocompatibility of a Novel ZK30-Cu-Mn Biomedical Alloy Produced by Selective Laser Melting. Int. J. Bioprinting 2021, 7, 78-89. [CrossRef] [PubMed]

12. Xie, B.; Zhao, M.; Tao, J.; Zhao, Y.; Yin, D.; Gao, C.; Shuai, C.; Atrens, A. Comparison of the biodegradation of ZK30 subjected to solid solution treating and selective laser melting. J. Mater. Res. Technol.-JMRET 2021, 10, 722-729.

13. Deng, B.; Guo, Y.X.; Zhao, M.C.; Li, Q.F.; Ma, B.; Duan, B.H.; Yin, D.F.; Atrens, A. Study on a Novel Biodegradable and Antibacterial Fe-Based Alloy Prepared by Microwave Sintering. Materials 2021, 14, 3784. [CrossRef]

14. Zhao, Y.; Tang, Y.; Zhao, M.; Liu, C.; Liu, L.; Gao, C.; Shuai, C.; Atrens, A. Study on Fe-xGO Composites Prepared by Selective Laser Melting: Microstructure, Hardness, Biodegradation and Cytocompatibility. JOM 2020, 72, 1163-1174. [CrossRef]

15. Tolouei, R.; Harrison, J.; Paternoster, C.; Turgeon, S.; Chevallier, P.; Mantovani, D. The use of multiple pseudo-physiological solutions to simulate the degradation behavior of pure iron as a metallic resorbable implant: A surface-characterization study. Phys. Chem. Chem. Phys. 2016, 18, 19637-19646. [CrossRef] [PubMed]

16. Liu, P.S. Determining Methods for Aperture and Aperture Distribution of Porous Materials. Titan. Ind. Prog. 2006, 2, 29-34.

17. GB/T 3850-2015; Impermeable Sintered Metal Materials and Hardmetals-Determination of Density. China Standards Press: Beijing, China, 2016.

18. Tao, S.C.; Xu, J.L.; Yuan, L.; Luo, J.M.; Zheng, Y.F. Microstructure, mechanical properties and antibacterial properties of the microwave sintered porous Ti-3Cu alloys. J. Alloys Compd. 2020, 812, 152142. [CrossRef]

19. Kato, H.; Todaka, Y.; Umemoto, M.; Haga, M.; Sentoku, E. Sliding wear behavior of sub-microcrystalline pure iron produced by high-pressure torsion straining. Wear 2015, 336, 58-68. [CrossRef]

20. Zhang, W.; Zhao, M.C.; Wang, Z.B.; Tan, L.; Qi, Y.; Yin, D.F.; Yang, K.; Atrens, A. Enhanced initial biodegradation resistance of the biomedical $\mathrm{Mg}-\mathrm{Cu}$ alloy by surface nanomodification. J. Magnes. Alloy. 2022, 10. in Press. [CrossRef]

21. Yan, X.; Zhao, M.; Yang, Y.; Tan, L.; Zhao, Y.; Yin, D.; Yang, K.; Atrens, A. Improvement of biodegradable and antibacte-rial properties by solution treatment and micro-arc oxidation (MAO) of a magnesium alloy with a trace of copper. Corros. Sci. 2019, 156, 125-138. [CrossRef]

22. Zhao, Y.; Tang, Y.; Zhao, M.; Liu, L.; Gao, C.; Shuai, C.; Zeng, R.; Atrens, A.; Lin, Y. Graphene oxide reinforced iron matrix composite with enhanced biodegradation rate prepared by selective laser melting. Adv. Eng. Mater. 2019, 21, 1900314. [CrossRef]

23. Cheng, J.; Zheng, Y.F. In vitro study on newly designed biodegradable Fe-X composites (X=W, CNT) prepared by spark plasma sintering. J. Biomed. Mater. Res. B 2013, 101B, 485-497. [CrossRef] [PubMed]

24. Tao, J.; Zhao, M.; Zhao, Y.; Yin, D.; Liu, L.; Gao, C.; Shuai, C.; Atrens, A. Influence of graphene oxide (GO) on microstructure and biodegradation of ZK30-xGO composites prepared by selective laser melting. J. Magnes. Alloy. 2020, 8, 952-962. [CrossRef]

25. Ji, H.; Zhao, M.C.; Xie, B.; Zhao, Y.C.; Yin, D.; Gao, C.; Shuai, C.; Andrej, A. Corrosion and antibacterial performance of novel selective-laser-melted (SLMed) Ti-xCu biomedical alloys. J. Alloys Compd. 2021, 864, 158415. [CrossRef]

26. Annamalai, R.; Upadhyaya, A.; Agrawal, D. An investigation on microwave sintering of Fe, $\mathrm{Fe}-\mathrm{Cu}$ and $\mathrm{Fe}-\mathrm{Cu}-\mathrm{C}$ alloys. Bull. Mater. Sci. 2013, 36, 447-456. [CrossRef]

27. Peuster, M.; Wohlsein, P.; Brúgmann, M.; Ehlerding, M.; Seidler, K.; Fink, C.; Brauer, H.; Fischer, A.; Hausdorf, G. A novel approach to temporary stenting: Degradable cardiovascular stents produced from corrodible metal-results 6-18 months after implantation into New Zealand white rabbits. Heart 2001, 86, 563-569. [CrossRef] [PubMed]

28. Duck, K.A.; Connor, J.R. Iron uptake and transport across physiological barriers. Biometals 2016, 29, 573-591. [CrossRef] [PubMed]

29. Zhu, S.; Huang, N.; Xu, L.; Zhang, Y.; Liu, H.; Sun, H.; Leng, Y. Biocompatibility of pure iron: In vitro assessment of degradation kinetics and cytotoxicity on endothelial cells. Mater. Sci. Eng. C 2009, 29, 1589-1592. [CrossRef]

30. Yamamoto, A.; Honma, R.; Sumita, M. Cytotoxicity evaluation of 43 metal salts using murine fibroblasts and osteoblastic cells. J. Biomed. Mater. Res. 1998, 39, 331-340. [CrossRef] 